\title{
Hubungan Perhatian Orangtua terhadap Kemandirian Anak Usia Dini di RA Jannatu 'Adn Purwakarta Tahun Pelajaran 2019-2020
}

\author{
Dede Hikmah \\ STAI DR. KH. EZ. Muttaqien Purwakarta \\ hikmahdede69@gmail.com \\ Didin Syaprudin \\ STAI DR. KH. EZ. Muttaqien Purwakarta \\ didinsyaprudin@gmail.com \\ Miftachul Jannah \\ STAI DR. KH. EZ. Muttaqien Purwakarta \\ jannahmiftachul92@gmail.com
}

DOI: https://doi.org/10.52593/pdg.02.1.03

Naskah diterima: 29 Agustus 2020, direvisi: 8 Januari 2021, disetujui: 12 Januari 2021

\begin{abstract}
Abstraksi
Penelitian ini bertujuan untuk mengetahui hubungan perhatian orangtua dengan kemandirian anak usia dini di RA. Jannatu 'Adn Purwakarta tahun pelajaran 2019-2020. Penelitian dilakukan dengan pendekatan kuantitatif menggunakan metode deskriptif. Teknik pengumpulan data dengan pengambilan sampel dari jumlah populasi. Sedangkan analisis kuantitatif dengan menggunakan analisis deskriptif, uji prasyarat analisis, analisis uji hipotesis, analisis korelasi dan regresi dengan menggunaakan bantuan software SPSS. Adapun indikator teori yang digunakan untuk variabel X (perhatian) dari Slameto yakni pemberian bimbingan belajar, nasehat, motivasi dan penghargaan, memenuhi kebutuhan, dan pengawasan, sedangkan untuk variabel Y (kemandirian) dari Carl Rogers yaitu percaya diri, motivisi tinggi, berani mengambil keputusan, kreatif dan inovatif, bertanggungjawab, mampu beradaptasi, tidak ketergantungan pada orang lain. Berdasarkan hasil analisis diketahui perhatian orangtua berkualifikasi cukup yakni (60,94\%). Sedangkan kemandirian anak usia dini berkualifikasi cukup yakni $(61,94 \%)$. Koefisien korelasi kedua variabel adalah sebesar 0,531 dan termasuk korelasi sedang dengan arah korelasi positif. Berdasarkan hasil uji hipotesis dengan menggunakan Uji T dengan bantuan software (Independent sample t-test), diperoleh Thitung 3,766 > Ttabel 2,034 dengan nilai sig (2 tailed) $(0,000)<\alpha(0,05)$, maka Ho ditolak dan menerima Ha. Dengan demikian terdapat hubungan perhatian orangtua terhadap kemampuan kemandirian anak usia dini di RA. Jannatu 'Adn Purwakarta tahun pelajaran 2019-2020. Besarnya hubungan perhatian orangtua terhadap kemandirian anak usia dini sebesar $28,1 \%$. Hal ini berarti bahwa selain perhatian orangtua, masih terdapat faktor lain sebesar $71,9 \%$ yang dapat mempengaruhi kemandirian anak usia dini di RA. Jannatu 'Adn Purwakarta tahun pelajaran 2019-2020.
\end{abstract}

Kata Kunci: Perhatian, Kemandirian, Orangtua 


\section{A. Pendahuluan}

Karakter menjadi salah satu skill abad 21 yang harus dimiliki oleh peserta didik dan menjadi dasar pembelajaran di sekolah, karenanya penguatan karakter untuk siswa harus diberikan sejak pendidikan usia dini. ${ }^{1}$ Salah satu yang harus mendapatkan perhatian pada anak usia dini adalah pengembangan karakter kemandirian. Secara khusus kemandirian menuntut kesiapan individu, baik secara fisik maupun emosional unuk mengatur, mengurus, dan melakukan aktvitas atas tanggung jawabnya sendiri tanpa banyak menggantungkan diri pada orang lain.

Kemandirian pada anak sangat penting bagi anak karena dapat mempengaruhi kehidupan anak kedepannya, dimana anak akan memiliki rasa percaya diri dalam menjaga kebersihan diri dan lingkungan, mengurus diri sendiri, dan menyelesaikan masalah yang dihadapi, selain itu anak juga jadi mampu dan berani menentukan pilihannya sendiri, anak akan memiliki motivasi instrinsik yang tinggi, anak akan jadi kreatif dan inovatif, anak akan bertanggung jawab atas keputusannya, anak akan mampu menyesuaikan diri dengan lingkungan, dan tidak tergantung pada orang lain.

Berkembangnya kemandirian anak tidak lepas dari peran orang tua, guru, pengasuh, maupun lingkungan anak itu sendiri, dimana orang tua ataupun guru mengasuh, membimbing, dan membantu mengarahkan anak untuk mandiri. Selain itu orang tua ataupun guru bisa memberikan kesempatan dan kepercayaan kepada anak untuk melakukan sendiri latihan kemandirian yang praktis seperti memakai baju, kaos kaki dan sepatu sendiri, makan sendiri, dan membereskan mainan yang sudah digunakan.

Orang tua adalah teladan bagi anak. Tidak dapat disangkal bahwa contoh dari orang tua mempunyai pengaruh yang sangat kuat bagi anak. Orangtua merupakan model yang pertama dan terdepan bagi anak (baik positif atau negatif). ${ }^{2}$

Orang tua perlu mengetahui keadaan anak dengan tepat, mendidik anak yang tepat yaitu dengan hati-hati dalam membimbingnya. Orang tua mendidik anaknya dengan tepat supaya menjadi anak yang diinginkan oleh orang tua dan menjadi anak yang memiliki kemandirian. Sebagaimana dalam sebuah keterangan hadits Rasulullah mengatakan "Setiap anak cucu adam (manusia) dilahirkan secara fitrah (suci). Maka orangtuanya-lah yang menjadikannya Majusi, Nashrani atau Yahudi”. Dalam konteks kemandirian, maka peran dan perhatian orangtua memegang peranan yang sangat penting dalam pembentukan kemandirian anak usia dini.

\footnotetext{
${ }^{1}$ TR, Burhanuddin., Nuur Majid, and Rizki Hikmawan. 2018. "Implementation of Character Education Using Islamic Studies in Elementary School Teacher Training." In 4th International Conference on Teacher Training and Education (ICTTE 2018) Implementation, 262:383-87. Atlantis Press. https://doi.org/10.2991/ictte-18.2018.71.

${ }^{2}$ Syamsu Yusuf, LN, Psikologi Perkembangan Anak dan Remaja, (Bandung: PT Remaja Rosdakarya, 2011),47.
} 


\section{B. Teori/ Konsep}

\section{Perhatian Orangtua}

Slameto menyatakan bahwa perhatian adalah kegiatan yang dilakukan seseorang dalam hubungannya dengan pemilihan rangsangan yang dating dari lingkunganny. ${ }^{3}$ Sumadi Suryabrata mengatakan bahwa perhatian adalah pemusatan tenaga psikis tertuju pada objek tertentu juga perhatian adalah banyak sedikitnya kesadaran yang menyertai sesuatu aktifitas yang dilakukan. ${ }^{4}$

Perhatian orang tua adalah kesadaran jiwa orang tua untuk memperdulikan anaknya, terutama dalam hal memenuhi dan memberikan kebutuhan pendidikan kepada anak bagi dari segi emosi maupun material. perhatian orangtua adalah pengarahan dan pemusatan tenaga terhadaap fasilitas yang bersifat material maupun sepiritual dalam memberikan kesempatan pada anak untuk memperoleh hasil prestasi yang optimal. ${ }^{5}$ Dengan demikian perhatian orang tua merupakan pemusatan atau konsentrasi orang tua terhadap anaknya yang menyebabkan bertambahnya aktivitas orang tua yang ditujukan kepada anak-anaknya terutama dalam pemenuhan kebutuhan baik secara fisik maupun non fisik. Bentuk kasih sayang orang tua yang merupakan perhatian orang tua terhadap anaknya sangat beragam. Misalnya orang tua memberi dorongan belajar kepada anak agar mencapai prestasi yang memuaskan. Selain itu orang tua yang membimbing kegiatan belajar anak yaitu dalam penyediaan waktu belajar. Juga orang tua yang memperhatikan tentang maju mundurnya belajar anak.

Bentuk kepedulian orang tua terhadap anaknya meliputi penyediaan fasilitas belajar. Ada juga yang setiap kenaikan kelas orang tua membelikan seragam sekolah baru. Dan menjadi teman diskusi mengenai pelajaran anak. Bentuk simpati orang tua terhadap keadaan anak yaitu bantuan mengatasi masalah sewaktu anak mengalami kesulitan dalam mengerjakan pekerjaan rumah. Selain itu orang tua yang memberi penghargaan pada anak setelah anaknya mendapatkan nilai yang bagus. Pada saat hasil ulangan anak jelek, orang tua tetap memberi semangat kepada anak agar anak tetap bersemangat dan berusaha supaya yang akan datang nilainya dapat lebih bagus dari yang sudah-sudah.

Bentuk-bentuk perhatian orangtua diantaranya adalah pemberian bimbingan belajar, memberikan nasehat, memberikan motivasi dan penghargaan, memenuhi kebutuhan anaknya, dan pengawasan terhadap anaknya. ${ }^{6}$

\footnotetext{
3 Slameto, Belajar dan Faktor-Faktor Yang Mempengaruhinya (Jakarta:Rineka Cipt, 2013), 105.

${ }^{4}$ Sumadi Suryabrata, Psikologi Pendidikan (Jakarta: Grafindo Persada, 2013), 14

${ }^{5}$ Rizka Iftikhah, Pengaruh Perhatian Orang Tua Terhadap Motivasi Belajar Siswa (Semarang: Jurnal Ilmiah Pendidikan Bimbingan dan Konseling IKIP Veteran Semarang, 2012), 87

${ }^{6}$ Desi Dwi Jayanti, "Pengaruh Perhatian Orangtua Terhadap Keterampilan Sosial Remaja Di Desa Ciracas Kecamatan Kiarapedes Kabupaten Purwakarta”. Purwakarta: STAI. DR.KHEZ. Muttaqien. t.d. 14-18.
} 


\section{Kemandirian}

Istilah "kemandirian" berasal dari kata dasar "diri" yang mendapat awalan "ke" dan akhiran "an", kemudian membentuk satu kata keadaan atau kata benda. Karena kemandirian berasal dari kata dasar "diri”,(Nurpratiwi, 2021) maka pembahasan mengenai kemandirian tidak bisa lepas dari pembahasan tentang perkembangan diri itu sendiri yang dalam konsep Carl Rogers disebut dengan istilah self, karena diri itu merupakan inti dari kemandirian. Konsep yang sering digunakan atau berdekatan dengan kemandirian adalah autonomy. ${ }^{7}$

Menurut Chaplin dalam Desmita, otonomi adalah kebebasan individu manusia untuk memilih, untuk menjadi kesatuan yang bisa memerintah, menguasai dan menentukan dirinya sendiri. Sedangkan Seifert dan Hoffnung mendefinisikan otonomi atau kemandirian sebagai "the ability to govern and regulate one's own thoughts, feelings, and actions freely and responsibly while overcoming feelings of shame and doubt."8

Secara singkat dapat disimpulkan bahwa kemandirian mengandung pengertian:

1) Suatu kondisi dimana seseorang memiliki hasrat bersaing untuk maju demi kebaikan dirinya sendiri.

2) Mampu mengambil keputusan dan insiatif untuk mengatasi masalah yang dihadapi.

3) Memiliki kepercayaan diri dan melaksanakan tugas-tugasnya.

4) Bertanggung jawab atas apa yang dilakukannya. ${ }^{9}$

Steinberg membedakan karakteristik kemandirian atas tiga bentuk kemandirian, yaitu:

a) Kemandirian emosional (emotional autonomy), yaitu aspek kemandirian yang menyatakan perubahan kedekatan hubungan emosional antar individu, seperti hubungan emosional antar individu, seperti hubungan emosional peserta didik dengan guru atau orang tuanya.

b) Kemandirian tingkah laku (behavioral autonomy), yaitu suatu kemampuan untuk membuat keputusan-keputusan tanpa tergantung pada orang lain dan melakukannya secara bertanggung jawab.

c) Kemandirian nilai (value autonomy), yaitu kemampuan memaknai seperangkat prinsip tentang benar dan salah, tentang apa yang penting dan apa yang tidak penting.

Perubahan yang paling penting dalam perkembangan anak ialah meningkatnya kemandirian. Pada aanak usia pra-sekolah merupakan fase perkembaangan individu sekitar $2-6$ tahun, ketika anak mulai memiliki

\footnotetext{
${ }^{7}$ Desmita, PsikologiPerkembanganPesertaDidik (Bandung:Rosda, 2012), 185

${ }^{8}$ Desmita, PsikologiPerkembanganPesertaDidik (Bandung:Rosda, 2012), 185.

${ }^{9}$ Desmita, PsikologiPerkembanganPesertaDidik (Bandung:Rosda, 2012), 184

22 | Paedagogie: p-ISSN: 2337-6848, e-ISSN : 2723-5971
} 
kesadaran dirinya sebagai pria atau wanita, dapat mengatur diri dalam berpakian, makan, buang air (toilet training) hingga mengenal beberapa hal yang dianggap berbahaya atau mencelakakan dirinya. Menurut Piaget, perkembangan kognitif pada usia ini berada pada periode praoperasional. Merupakan tahapan ke dua yang berlangsung dari usia $2-7$ tahun. Pada tahapan ini anak belum mampu menguasai operasi mental secara logis. Dalam teori Piaget operasi adalah serangkaian aksi yang diinternalisasi yang memungkinkan anak-anak melakukan secara mental apa yang dulunya mereka lakukan secara fisik. ${ }^{10}$ Pada periode ini berkembang kemampuan representasional atau "simbolic function" yaitu kemampuan menggunakan sesuatu untuk merepresentasikan (mewaakili) sesuatu yang lain dengan menggunakan symbol (kata-kata, gesture/bahasa gerak, dan benda). Dapat pula disebut sebagai "semiotic function" yaitu sebuah kemampuan untuk menggunakan symbol-simbol (bahasa, gambar, tanda/isyarat, benda,gesture, peristiwa) untuk melambangkan suatu kegiatan benda yang nyata atau peristiwa nyata. ${ }^{11}$

Mengutip Artikel dalam situs resmi (pusatkemandiriananak.com) bahwa indicator kemandirian pada anak usia dini adalah sebagai berikut: ${ }^{12}$

1) Kepercayaan pada diri sendiri.

Rasa percaya diri, atau dalam kalangan anak muda biasa disebut dengan istilah 'PD'ini sengaja ditempatkan sebagai ciri pertama dari sifat kemandirian anak, karena memang rasa percaya diri ini memegang peran penting bagi seseorang, termasuk anak usia dini, dalam bersikap dan bertingkah laku atau dalam beraktivitas sehari-hari. Anak yang memiliki kepercayaan diri lebih berani untuk melakukan sesuatu, menentukan pilian sesuai dengan kehendaknya sendiri dan bertanggung jawab terhadap konsekwensi yang ditimbulkan karena pilihannya. Kepercayaan diri sangat terkait dengan kemandirian anak. Dalam kasus tertentu, anak yang memiliki percaya diri yang tinggi dapat menutupi kekurangan dan kebodohan yang melekat pada dirinya. Oleh karena itu, dalam berbagai kesempatan, sikap percaya diri perlu ditanamkan dan dipupuk sejak awal pada anak usia dini ini.

2) Motivasi instrinsik yang tinggi

Motivasi instrinsik adalah dorongan yang tumbuh dalam diri untuk melakukan sesuatu. Motivasi instrinsik biasanya lebih kuat dan abadi dibandingkan dengan motivasi ekstrinsik walupun kedua motivasi ini kadang berkurnag, tapi kadang juga bertambah. Kekuatan yang datang dari dalam akan mampu menggerakkan untuk melakukan sesuatu yang diinginkan. Keingintahuan seseorang yang murni adalah merupakan salah satu contoh

10 John W. Samtrock, Life-Span Development-Perkembangan Masa Hidup Edisi ketiga Belas Jilid I, (Jakarta: Erlangga, 2011), 248.

11 Yusuf, Syamsu LN, Psikologi Perkembangan Anak dan Remaja, (Bandung: Rosda, 2015), 165.

12 https://pusatkemandiriananak.com/memahami-perilaku-kemandirian-anak-usia-dini/ (Diakses: Senin, 9 November 2019 Pukul 21.30 wib). 
motivsasi instrinsik. Dengan adanya keingintahuan yang mendalam ini dapat mendorong seseorang untuk melakukan sesuatu yang memungkinkan ia memperoleh apa yang dicita-citakannya. Dengan keinginan dan tekad yang kuat, orang biasanya menjadi lupa waktu, keadaan, dan bahkan lupa diri sendiri.

3) Mampu dan berani menentukan pilihan sendiri.

Anak mandiri memiliki kemampuan dan keberanian dalam menentukan pilihan sendiri. Misalnya dalam memilih alat bermain atau alat belajar yang akan digunakannya.

4) Kreatif dan inovatif

Kreatif dan inovatif pada anak usia dini merupakan ciri anak yang memiliki kemandirian, seperti dalam melakukan sesuatu atas kehendak sendiri tanpa disuruh oleh orang lain, tidak ketergantungan kepada orang lain dalam melakukan sesuatu, meyukai pada hal-hal baru yang semula dia belum tahu, dan selalu ingin mencoba hal-hal yang baru.

5) Bertanggung jawab menerima konsekwensi yang menyertai pilihannya.

Di dalam mengambil keputusan atau pilihan tentu ada konsekwensi yang melekat pada pilihannya. Anak yang mandiri dia bertanggung jawab atas keputusan yang diambilnya apapun yang terjadi tentu saja bagi anak Taman Kanak-kanak tanggung jawab pada taraf yang wajar. Misalnya tidak menangis ketika ia salah mengambil alat mainan, dengan senang hati mengganti dengan alat mainan yang lain yang diinginkannya.

6) Menyesuiaiakan diri dengan lingkungannya.

Lingkungan sekolah (Taman Kanak-kanak) merupakan lingkungan baru bagi anak-anak. Sering dijumpai anak menangis ketika pertama masuk sekolah karena mereka merasa asing dengan lingkungan di Taman Kanak-kanak bahkan tidak sedikit yang ingin ditunggui oleh orang tuanya ketika anak sedang belajar. Namun, bagi anak yang memiliki kemandirian, dia akan cepat menyesuaiakan diri degan lingkungan yang baru.

7) Tidak ketergantungan kepada orang lain

Anak mandiri selalu ingin mencoba sendiri-sendiri dalam melakukan sesuatu tidak bergantung pada orang lain dan anak tahu kapan waktunya meminta bantuan orang lain, setelah anak berusaha melakukannya sendiri tetapi tidak mampu untuk mendapatkannya, baru anak meminta bantuan orang lain. Seperti mengambil alat mainan yang berada di tempat yang tidak terjangkau oleh anak

\section{Metodologi Penelitian/ Kajian}

Pendekatan dalam penelitian ini menggunakan pendekatan kuantitatif dengan metode korelatif. Penelitian dilaksanakan di Penelitian dilaksanakan di RA. Janntu 'Adn Purwakarta. Berdasarkan data hasil observasi didapatkan data populasi jumlah 
siswa anak usia dini di RA. Janntu 'Adn Purwakarta tahun pelajaran 2019-2020 adalah sebesar 32 orang.

\section{Hasil dan Pembahasan}

\section{Deskripsi Perhatian Orangtua AUD}

Pengambilan data variabel $X$ (Perhatian orangtua) dilakukan dengan instrumen berupa angket tertutup skala likert kepada 32 sampel sebanyak 30 soal. Perhatian orangtua sebagai variabel $\mathrm{X}$ diketahui dari 5 indikator variabel yaitu : 1) memberikan bimbingan belajar, 2) memberikan nasehat, 3) memberikan motivasi dan penghargaan, 4) memenuhi kebutuhan anaknya, dan 5) memberikan pengawasan terhadap anaknya. Hasil analisis deskriptif variabel perhatian orangtua dapat dilihat pada tabel berikut ini:

Hasil Kategorisasi Variabel Perhatian Orangtua

\begin{tabular}{|c|l|c|c|c|c|}
\hline No & \multicolumn{1}{|c|}{ Indikator } & Skor & Rata-Rata & $\%$ & Kategori \\
\hline 1 & $\begin{array}{l}\text { memberikan bimbingan } \\
\text { belajar }\end{array}$ & 2.68 & 85.83 & 53.65 & Cukup Baik \\
\hline 2 & $\begin{array}{l}\text { memberikan nasehat } \\
\text { memberikan motivasi dan } \\
\text { penghargaan }\end{array}$ & 2.12 & 99.71 & 62.32 & Cukup Baik \\
\hline 4 & $\begin{array}{l}\text { memenuhi anaknya } \\
\text { ananan }\end{array}$ & 3.44 & 110.00 & 68.75 & Baik \\
\hline 5 & $\begin{array}{l}\text { memberikan pengawasan } \\
\text { terhadap anak }\end{array}$ & 3.32 & 106.25 & 66.41 & Cukup Baik \\
\hline
\end{tabular}

Secara keseluruhan, rentangan skor teoritis terendah yang mungkin dicapai sampel adalah 30 dan skor tertinggi 150. Total skor maksimal 32 sampel dengan angket 30 soal adalah 2925 atau sebesar 60,94\%. Dengan demikian orangtua sudah cukup baik dalam memberikan perhatian pada anak usia dini di RA. Jannatu 'And purwakartan. Gambaran mengenai perhatian orangtua di RA. Jannatu 'adn Purwakarta dideskripsikan melalui gambar berikut:

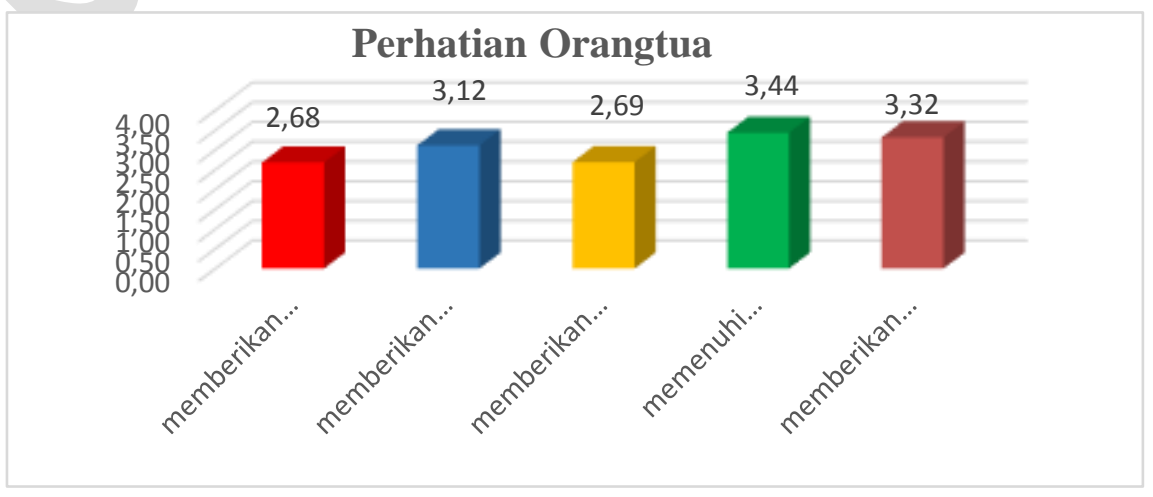

Gambar 4. 1. Gambaran Perhatian Orangtua 
Kesadaran jiwa orang tua untuk mempedulikan dan memberikan perhatian pada anaknya, terutama dalam memberikan dan memenuhi kebutuhan anaknya baik dalam segi emosi maupun materi sangat berperan dalam pembentukan karakter pada anak. Keluarga merupakan tempat pertama kali dan menajdi lembaga pendidikan yang paling utama bagi anak anak berkenalan dengan norma dan nilai. Walaupun perhatian orangtua dan pendidikan dalam keluarga tidak ada rumusan kurikulum dan program resmi dalam kegiatan pembelajaran, tapi apa yang anak peroleh melalui perhatian, interaksi dan keteladanan dalam keluarga sangat potensial dan mendasar bagi perkembangan anak secara sosial, emosional dan spiritual. ${ }^{13}$

\section{Deskripsi Kemandirian}

Pengambilan data variabel Y (kemandirian) dilakukan dengan instrumen berupa angket tertutup skala likert kepada 32 sampel sebanyak 30 soal. Perhatian orangtua sebagai variabel $\mathrm{X}$ diketahui dari tujuh indikator variabel yaitu : 1) kepercayaan pada diri sendiri, 2) motivasi instrinsik yang tinggi, 3) mampu dan berani menentukan pilihan sendiri, 4) kreatif dan inovatif, 5) bertanggung jawab menerima konsekuensi yang menyertai pilihannya, 6) menyesuaikan diri dengan lingkungannya, dan 7) tidak ketergantungan kepada orang lain. Hasil analisis deskriptif variabel kemandirian dapat dilihat pada tabel berikut ini:

Hasil Kategorisasi Variabel Kemandirian

\begin{tabular}{|c|c|c|c|c|c|}
\hline No & Indikator & Skor/skala & $\begin{array}{l}\text { Rata- } \\
\text { Rata }\end{array}$ & $\%$ & Kategori \\
\hline 1 & $\begin{array}{l}\text { Kepercayaan pada } \\
\text { diri sendiri. }\end{array}$ & 2.93 & 93.83 & 58.65 & Cukup Baik \\
\hline 2 & $\begin{array}{l}\text { Motivasi instrinsik } \\
\text { yang tinggi }\end{array}$ & 3.17 & 101.43 & 63.39 & Cukup Baik \\
\hline 3 & $\begin{array}{l}\text { Mampu dan berani } \\
\text { menentukan pilihan } \\
\text { sendiri. }\end{array}$ & 3.16 & 101.00 & 63.13 & Cukup Baik \\
\hline 4 & Kreatif dan inovatif & 2.69 & 86.00 & 53.75 & Cukup Baik \\
\hline 5 & $\begin{array}{ll}\text { Bertanggung } & \text { jawab } \\
\text { menerima } & \\
\text { konsekuensi yang } \\
\text { menyertai } & \\
\text { pilihannya } & \\
\end{array}$ & 2.93 & 93.60 & 58.50 & Cukup Baik \\
\hline 6 & $\begin{array}{ll}\text { Menyesuaikan diri } \\
\text { dengan } \\
\text { lingkungannya }\end{array}$ & 3.59 & 115.00 & 71.88 & Baik \\
\hline 7 & $\begin{array}{l}\text { Tidak } \\
\text { ketergantungan } \\
\text { kepada orang lain }\end{array}$ & 3.70 & 118.33 & 73.96 & Baik \\
\hline
\end{tabular}

\footnotetext{
${ }^{13}$ https://www.kompasiana.com/almustafidatulilmi/58a40195d69373d03bdafd87/perhatian -orang-tuaterhadap-anak-secara-khusus. Oleh Ilmin diposting pada 15 februari 2017 pukul 14.22. Diakses pada kamis, 6 februari 2020 Pukul 10.05 wib.
} 
Secara keseluruhan, rentangan skor teoritis terendah yang mungkin dicapai sampel adalah 30 dan skor tertinggi 150. Total skor maksimal 32 sampel dengan angket 30 soal adalah 2973 atau sebesar 58,06\%. Dengan demikian anak usia dini di RA. Jannatu 'Adn purwakartan memiliki kemandirian cukup baik. Gambaran mengenai kemandirian anak usia dini di RA. Jannatu 'adn Purwakarta dideskripsikan melalui gambar berikut:

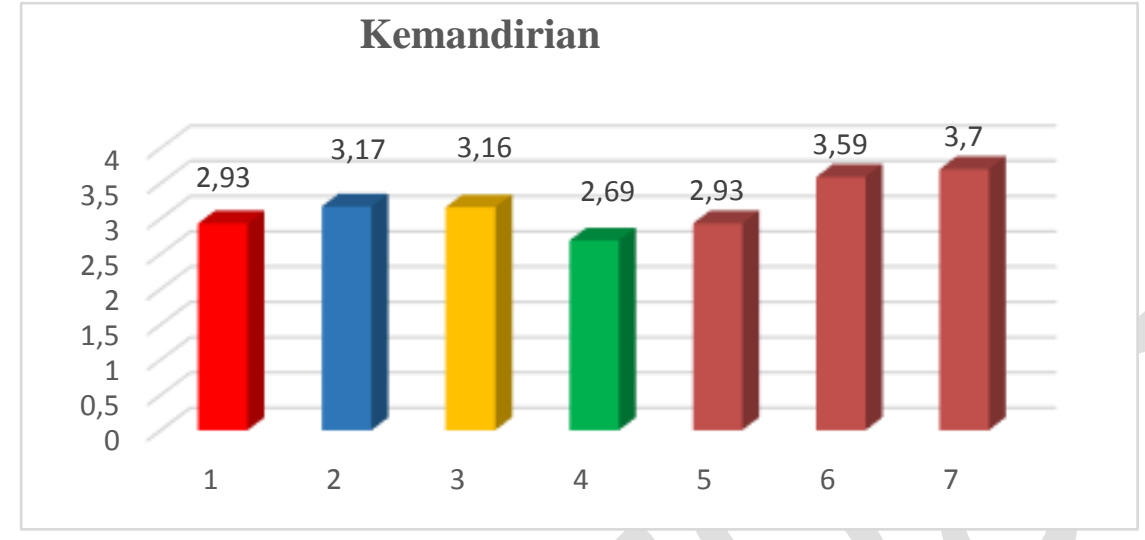

\section{Gambar Deskripsi Perhatian Orangtua}

\section{Keterangan:}

1) Kepercayaan pada diri sendiri.

2) Motivasi instrinsik yang tinggi

3) Mampu dan berani menentukan pilihan sendiri.

4) Kreatif dan inovatif

5) Bertanggung jawab menerima konsekuensi yang menyertai pilihannya

6) Menyesuaikan diri dengan lingkungannya

7) Tidak ketergantungan kepada orang lain

Mengajarkan anak berperilaku mandiri harus dilakukan sejak usia dini. Ini karena kemandirian berkaitan erat dengan karakter dan sikap anak di masa depan. Bila dari kecil tidak dilatih untuk mandiri, besar kemungkinan anak akan tumbuh menjadi pribadi yang manja. Perilaku mandiri juga membangun rasa tanggung jawab tinggi pada anak.

Dalam melatih kemandirian anak, orang tua harus ekstra sabar karena memang tidak mudah mengajar anak-anak. Selain itu perlu diingat, melatih anak mengerjakan sesuatu terkadang butuh proses berulang sampai akhirnya sang anak terbiasa untuk melakukannya. Menurut Amy McCready, pendiri Positive Parenting Solutions, orang tua bisa memberikan satu tugas secara reguler. "Tugastugas sederhana yang secara konsisten diberikan kepada Anak akan efektif dalam melatih kemandiriannya," kata McCready dikutip dari Parents.com. McCready menjelaskan yang dimaksud dengan perilaku mandiri adalah sikap anak yang dalam melakukan atau memutuskan sesuatu tidak bergantung dengan sekitarnya. 
Kemandirian anak ditandai dengan adanya kemampuan untuk melakukan aktivitas sederhana sehari-hari. Kemandirian akan dicapai oleh anak melalui proses belajar. Oleh karena itu ketika melatih kemandirian anak, Michelle La Rowe, penulis buku A Mom's Ultimate Book of Lists mengatakan, jangan memberi tugas yang sulit. "Berikan tugas yang bisa dilakukan anak-anak tanpa menemui kesulitan. Misalnya, memakai dan menalikan tali sepatu sendiri atau mengenakan jaket sendiri," ujar La Rowe. Bagian dari kemandirian adalah kemampuan membuat keputusan sendiri. Jadi biarkan anak membuat keputusan sendiri. Selain itu, kemandirian berkaitan erat dengan kemampuan anak dalam menyelesaikan masalah. Perilaku mandiri ditunjukkan dengan adanya kemampuan untuk mengambil inisiatif dan mengatasi masalah, serta ingin melakukan sesuatu tanpa bantuan orang lain. ${ }^{14}$

\section{Hubungan perhatian orangtua dengan kemandirian}

Analisis dilakukan dengan bantuan software dengan taraf signifikasi 5\% $(0,05)$. Hasil uji prasyarat analisis menunjukkan kedua data memiliki data berdistribusi normal, homogeny dan linear. Hasil analisa korelasi dengan menggunakan Pearson (Product Moment) memaparkan nilai koefesien korelasi sebesar 0,531 (hubungan korelasi sedang dengan arah korelasi positif). Sedangkan hasil koefesien determinasi sebesar 0,281. Hal tersebut mengindikasikan bahwa $28,1 \%$ variabel $\mathrm{Y}$ turut ditentukan oleh variabel $\mathrm{X}$, sedangkan sisanya $71,9 \%$ ditentukan oleh variabel lain yang perlu diteliti.

Berdasarkan hasil uji hipotesis dengan menggunakan Uji T dengan bantuan software (Independent sample t-test), diperoleh Thitung 3,766 > Ttabel 2,034 dengan nilai sig (2 tailed) $(0,000)<\alpha(0,05)$, maka Ho ditolak dan menerima Ha. Dengan demikian maka dapat disimpulkan bahwa hipotesis terdapat hubungan Perhatian orangtua dengan kemandirian anak usia dini di RA. Jannatu 'Adn Purwakarta tahun pelajaran 2019-2020 terbukti atau diterima.

Berdasarkan hasil pengujian signifikasi dan linearitas seperti pada tabel di atas, dapat diketahui bahwa regresi $\mathrm{Y}=59,778+0,545 \mathrm{X}$ sangat signifikan dan linear. Model regresi tersebut mengandung arti bahwa apabila Perhatian orangtua mengalami penurunan satu poin, maka kemandirian cenderung meningkat sebesar 0,545 poin pada konstanta 59,778 .

Kepedulian dan perhatian orangtua menjadi kunci sukses melatih kemandirian anak. Tak sedikit orang tua yang melarang buah hatinya ketika anak ingin mencoba hal baru. Padahal mencoba sesuatu yang baru berhubungan dengan keman dirian dan membangun intelektual anak. "Anak-anak harus diberikan ke percayaan untuk melakukan aktivitas baru. Tidak sedikit orang tua yang khawatir jika anaknya dilepas sendiri. Padahal mencoba hal baru ber kaitan erat dengan

\footnotetext{
${ }^{14}$ Sri Noviani, "Pentingnya Melatih Kemandirian Sejak Dini” dalam http://koransindo.com/page/news/2017-08-25/4/16/Pentingnya_Melatih_Kemandirian_Anak_Sejak_Dini edisi 25 Agustus 2017. Diakses kamis, 6 Februari 2020 pukul 09.14.
} 
kemandirian. Ketakutan orang tua bisa di rasakan oleh anak, sehingga ini membuat anak lambat untuk mandiri," Kemandirian amat ber dam pak positif bagi per kembangan anak sehingga sangat baik jika kemandirian ini diajarkan sedini mungkin dengan disesuaikan pada kemampuan dan usia anak," imbuh Shierly.

Selain di rumah, sekolah juga memiliki peran besar untuk membangun kemandirian anak. Karenanya orang tua harus jeli dalam mempersiapkan dan juga memilih sekolah untuk sang buah hati. Dalam Sindonews.com, Novani menjelaskan terdapat beberapa tips mengasah kemandirian anak ${ }^{15}$ :

\section{Merapikan Tempat Tidur Sendiri}

Merapikan tempat tidur merupakan kebiasaan yang tepat untuk menumbuhkan percaya diri pada anak. Hal ini mungkin terlihat sederhana, namun akan berdampak terhadap pembentukan karakter anak masa mendatang.

\section{Mengambil Makanan Sendiri}

Sikap kemandirian juga bisa dapat diajarkan di meja makan. Sesekali, biarkan anak mengambil makanannya sendiri tanpa dibantu. Dalam hal ini yang perlu dilakukan adalah mengajarkan cara mengambil makanan yang baik, sopan dan secukupnya. Selain ajarkan juga etika dan cara makan yang pada anak.

\section{Merapikan Mainan}

Anak-anak memang identik dengan meninggalkan mainan di mana saja. Untuk membentuk kepribadiannya, maka mulailah mengajarkan anak untuk menyimpan dan merapikan mainannya sendiri. Langkah-langkah sederhana ini bisa menjadi cara yang efektif dalam menumbuhkan kemandirian pada anak. Langkah sederhana namun berkualitas justru lebih mudah dipelajari oleh anak. Peran orang tua sangat diperlukan agar anak terbiasa dan tidak merasa terpaksa dalam melakukan hal-hal sederhana ini.

\section{E. Simpulan}

Berdasarkan penelitian yang telah dilakukan dilengkapi dengan analisis data penelitian sebagaimana rumusan masalah, tujuan penelitian dan hipotesis penelitian maka dapat diambil simpulan sebagai berikut: Pertama, perhatian orangtua di RA. Jannatu 'Adn Purwakarta tahun pelajaran 2019-2020 diukur berdasarkan 5 indikator variabel yaitu: 1) memberikan bimbingan belajar, 2) memberikan nasehat, 3) memberikan motivasi dan penghargaan, 4) memenuhi kebutuhan anaknya, dan 5) memberikan pengawasan terhadap anaknya. Hasil penelitian menunjukkan orangtua sebesar 60,94\%. Dengan demikian orangtua siswa usia dini di RA. Jannatu 'Adn tahun pelajaran 20192020 memberikan perhatian cukup baik terhadap anak; Kedua, Kemandirian anak usia

\footnotetext{
${ }^{15}$ Sri Noviani, "Pentingnya Melatih Kemandirian Sejak Dini” dalam http://koransindo.com/page/news/2017-08-25/4/16/Pentingnya_Melatih_Kemandirian_Anak_Sejak_Dini edisi 25 Agustus 2017. Diakses kamis, 6 Februari 2020 pukul 09.14.
} 
dini di RA. Jannatu 'Adn Purwakarta tahun pelajaran 2019-2020 diukur berdasarkan tujuh indikator variabel yaitu: 1) kepercayaan pada diri sendiri, 2) motivasi instrinsik yang tinggi, 3) mampu dan berani menentukan pilihan sendiri, 4) kreatif dan inovatif, 5) bertanggung jawab menerima konsekuensi yang menyertai pilihannya, 6) menyesuaikan diri dengan lingkungannya, dan 7) tidak ketergantungan kepada orang lain. Hasil penelitian menunjukkan kemandirian anak usia dini sebesar 61,94\%. Dengan demikian, anak usia dini di di RA. Jannatu 'Adn tahun pelajaran 2019-2020 memiliki kemandirian cukup baik; Ketiga, Terdapat hubungan Perhatian orangtua dengan kemandirian anak usia dini di RA. Jannatu 'Adn Purwakarta tahun pelajaran 2019-2020. Besarnya pengaruh berdasarkan hasil analisis koefisien determinasi 0,281. Hal tersebut menunjukkan terdapat hubungan Perhatian orangtua dengan kemandirian anak usia dini di RA. Jannatu 'Adn Purwakarta tahun pelajaran 2019-2020 sebesar 28,1\%.

\section{Daftar Pustaka}

Agustini, A. 2015. Pengaruh Perhatian Orangtua Terhadap Akhlak Siswa. Purwakarta: STAI.DR.KHEZ.Muttaqien (Skripsi Tidak Diterbitkan).

Ahmadi, A. 2003. Psikologi Umum. Jakarta: Rineka Cipta.

Arikunto, S. 2010. Prosedur Penelitian Suatu Pendekatan Praktik. Jakarta: Rineka Cipta, 2010.

Asmawati,E. 2009. Tanggapan Siswa Terhadap Kompetensi Guru Pendidikan Agama Islam Hubungannya Dengan Motivasi Belajar Siswa. Purwakarta: STAI.DR.KHEZ.Muttaqien (Skripsi Tidak Diterbitkan)

Asrori, M. 2009. Psikologi Pembelajaran. Bandung: CV.Wahana Prima.

Azizah, N. 2009. Hubungan Antara Perhatian Orang Tua dengan Prestasi Belajar Pendidikan Agama Islam Siswa Kelas VII SMPN 2 Temon Kulon Progo Tahun Pelajaran 2008/2009. Yogyakarta: UIN Sunan Kalijaga (Skripsi Tidak Diterbitkan).

Creswell, J. 2015. Riset Pendidikan Perencanaan, Pelaksanaan, dan Evaluasi Riset kualitatif dan Kuantitatif. Yogyakarta: Pustaka Pelajar.

Dakir. 1993. Dasar-Dasar Psikologi. Yogyakarta: Pustaka Pelajar.

Desmita. 2012. Psikologi Perkembangan Peserta Didik. Bandung: PT Remaja Rosdakarya.

Durachman. 2014. Peranan Orangtua, Guru, Dan Teman Sebaya Dalam Proes Pembentukan Kaakter Siswa Sekolah Dasar . Bandung: Prosiding UPI.

Iftikhah, R. 2012. Pengaruh Perhatian Orang Tua Terhadap Motivasi Belajar Siswa. Semarang: IKIP Veteran Semarang (Jurnal Ilmiah Pendidikan Bimbingan dan Konseling).

Mawarsih, S. E. 2013. Pengaruh Perhatian Orang Tua dan Motivasi Belajar terhadap Prestasi Belajar Siswa SMA Negeri Jumapolo. Semarang: Universitas Negeri Semarang (Jurnal Pendidikan Volume 1 Nomor 3).

Nurpratiwi, M. R. E. dan S. (2021). Hubungan Keberagamaan dan Perilaku Altruistik Mahasiswa. Al-Afkar, 4(1), 83-97.

https://doi.org/https://doi.org/10.31943/afkarjournal.v4i1.181 
Effendi, M. R., \& Nurpratiwi, S. (2021). H Hubungan Keberagamaan dan Perilaku Altruistik Mahasiswa. al-Afkar, Journal For Islamic Studies, 4(1).

Santrock, J. W. 2011. Life Span Development Perkembangan Masa Hidup Jilid I. Bandung: Erlangga.

Slameto. 2013. Belajar dan Faktor-Faktor Yang Mempengaruhinya. Jakarta:Rineka Cipta.

Sobur, A. 2003. Psikologi Umum. Bandung: Pustaka Setia.

Sugiyono. 2007. Metode Penelitian Pendidikan. Bandung: Alfabeta.

Suharsaputra, U. Metode Penelitian Kuantitaif Kualitatif dan Tindakan. Bandung:Refika Aditama.

Sumanto. 2014. Statistika Terapan. Yogyakarta: CAPS (Center of Academic Publishing Service Sugiyono. 2016. Metode Penelitian Kombinasi (Mix Methode). Bandung: Alfabeta.

Suryabrata.S. 2013. Psikologi Pendidikan . Jakarta: Grafindo Persada.

Syah, M. 1995. Psikologi Pendidikan Dengan Pendekatan baru. Bandung: Rosda.

Syifauzakia. 2014. Pentingnya Melatih Kemandirian Anak Sejak Dini Untuk Pencapaian

Kesiapan Sekolah. Bandung: Universitas Pendidikan Indonesia (Jurnal Prosiding Konferensi Pendidikan Dasar).

Tarigan, M. B. 2014. Meningkatkan Kemandirian Anak Taman Kanak-Kanak Melalui Metode Bermain Peran Makro. Bandung: Universitas Pendidikan Indonesia (Jurnal Prosiding Konferensi Pendidikan Dasar).

Trihendradi, C. 2010. SPSS 18 Analisis Data Statistik. Yogyakarta: CV. Andi Offest.

Yamin,S. dan Kurniawan,H., 2009. SPSS Complete Teknik Analisis Statistik Terlengkap Dengan Software SPSS. Jakarta: Salemba Infotek

Yusuf, Syamsu.LN. 2011. Psikologi Perkembangan Anak dan Remaja. Bandung: PT Remaja Rosdakarya. 